\section{Lidt om Valdemar Andersen som bindtegner}

Af thv. seniorforsker Harald Ilsøe

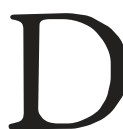

en eminent dygtige tegner Valdemar Andersen (1875-1928)

nyder stor anerkendelse som bladtegner, bogillustrator og plakatkunstner. Han beherskede snart sagt enhver stilart og udførte sine arbejder med sikker hånd, hvad enten det gjaldt en svulmende og kraftfuld, undertiden karikerende stil eller motiver fanget med enkle elegante streger. I sjælden grad mestrede han udformningen af bogomslag og benyttedes hertil af flere forlag (Gyldendal, V. Pio og John Martin). Virkningsfulde er ikke mindst de omslag, han udførte til Pios mange Kiplingudgaver ca. 1911-20, mere forfinede f.eks. tegningerne på nogle omslag om Martins udgaver i serien 'Dansk Bogsamling' fra 1920rne, som han iøvrigt også illustrerede. Mindre kendt er han som dekoratør af forlagsbind, forsåvidt rimeligt som han inden for dette felt kun løste et begrænset antal opgaver, men ikke rimeligt, når det tages $\mathrm{i}$ betragtning, at han også her viste sig som en fortræffelig, om end knap så spændende kunstner. I sin Valdemar Andersen-monografi indskrænker Poul Carit Andersen sig til en summarisk omtale af tolvbRÓdO¥serien 'Gyldendals Bibliothek' (Valdemar Andersen. En dansk tegner, 1975, s. 73), og mere er der ikke at hente i den nye udgave af Weilbachs kunstnerleksikon - snarere tværtimod, for de nævnte bind i 'Gyldendals Bibliothek' er ukorrekt rubriceret som bogomslag, og Valdemar Andersen krediteres overhovedet ikke for sine bind. Der kan derfor være anledning til supplere værkfortegnelsen med præsentationen af nogle VA-bind i det omfang, sådanne har ladet sig opspore.

Det gør det selvsagt vanskeligt, at forlagsbindene kun i fă tilfælde bærer kunstnersignatur, men undertiden fandt forlagene det opportunt at reklamere for en bog med henvisning til, at en bestemt kunstner stod for binddekorationen.

Dette var tilfældet med de tolv af Carit Andersen nævnte bind, der udkom 1911-12 som nr. 123-34 i serien 'Gyldendals Bibliothek', og finkæmmes annoncerne i det følgeblad, forlaget udsendte til abonnenterne, kan endnu fire bind føjes til. Heraf har forlaget direkte angivet seriens $\mathrm{nr} .16$ og 99 som VAbind, mens der blot reklameredes med VA og andre kunstnere en bloc som ansvarlige for bindene om et par årgange bestående af henholdsvis nr. 111-20 og 135-46, så det kun er muligt at udpege de pågældende kunstnere ved en kombination af stilkriterier og udelukkelsesmetode. Derved kan nr. 111 og nr. 137 dog uden større vaklen udpeges som sandsynlige VA-bind. Da endvidere nr. 80 undtagelsesvis viser sig at være signeret med hans initialer, bliver der tale om ialt sytten bind. Det er temmelig mange, og det ser ud til, at VA har været seriens mest benyttede bindkunstner efter Kristian Kongstad, klart Gyldendals favorit og mester for over fyrre bind.

Numrene er anført med forfattere og titler til sidst i artiklen. De 


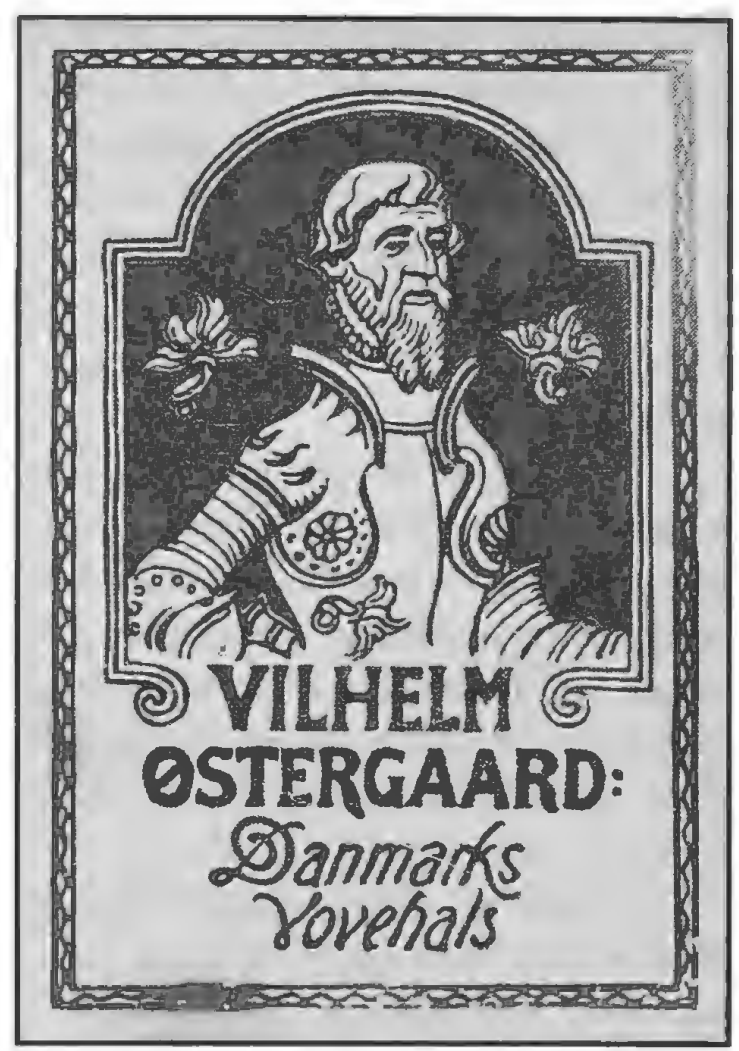

Nr. 129 i 'Gyldendals Bibliothek' i guld og gråblåt på hvid bund (1912).

fleste udmærker sig ved at være i delikate farver, kun nr. 123 og 129 er dekoreret med sort og guld på lys 'ufarvet' bund. Naturalistiske motiver veksler og blandes med rent dekorativ udsmykning. På bindet om Carsten Hauchs roman fra Christian IIs tid om Vilhelm Zabern (nr. 127) er midtertegningen parafraseret over et gammelt træsnit med København set fra søsiden, over og under dette er forfatter og titel prentet med gotiske bogstaver i forgyldning og udenom løber en bred ornamenteret bort. Nr. 129 bærer et morsomt portræt af Danmarks Vovehals Peder Skram i reliefskæring, som var det kopieret efter en gravsten. Naturmotiver er taget op på nr. 126 og 137. Sidstnæunte gælder Lasse Månsson fra Skaine og viser et skovbevokset landskab med blinkende søer. På nr. 126 ses et vildsvin der styrter gennem en ungskov, glimrende udført i guld på blåt. Bl.a. Drachmanns 'Fortællinger' (nr. 16) og Knut Hamsuns 'Victoria' (nr. 124) er rent dekorativt udsmykket.

$\mathrm{B}$ indene i Gyldendals serie er fra 1907-12, men forlaget havde benyttet Valdemar Andersen som tegner fra senest 1905. Han tegnede omslaget til subskriptionshefterne af en flerbindsudgave af Conan Doyle's detektivhistorier 1905-06 med titlen 'Sherlock Holmes Opdagelser (Forbryder-Fortallinger)', og da første bind nærmede sig afslutningen, averterede forlaget på bagsiden af et hefte, at der ville blive frem-

\section{Nr. 126 i 'Gyldendals Bibliothek' $i$ guld,} gråt og sort på morkeblå bund (1911).

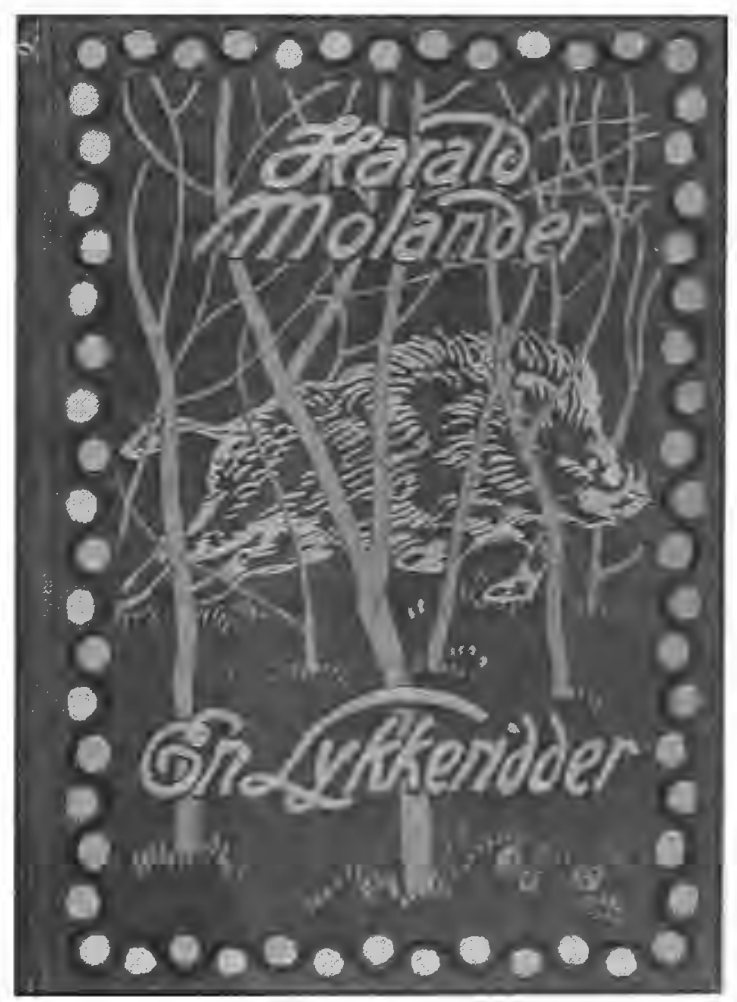




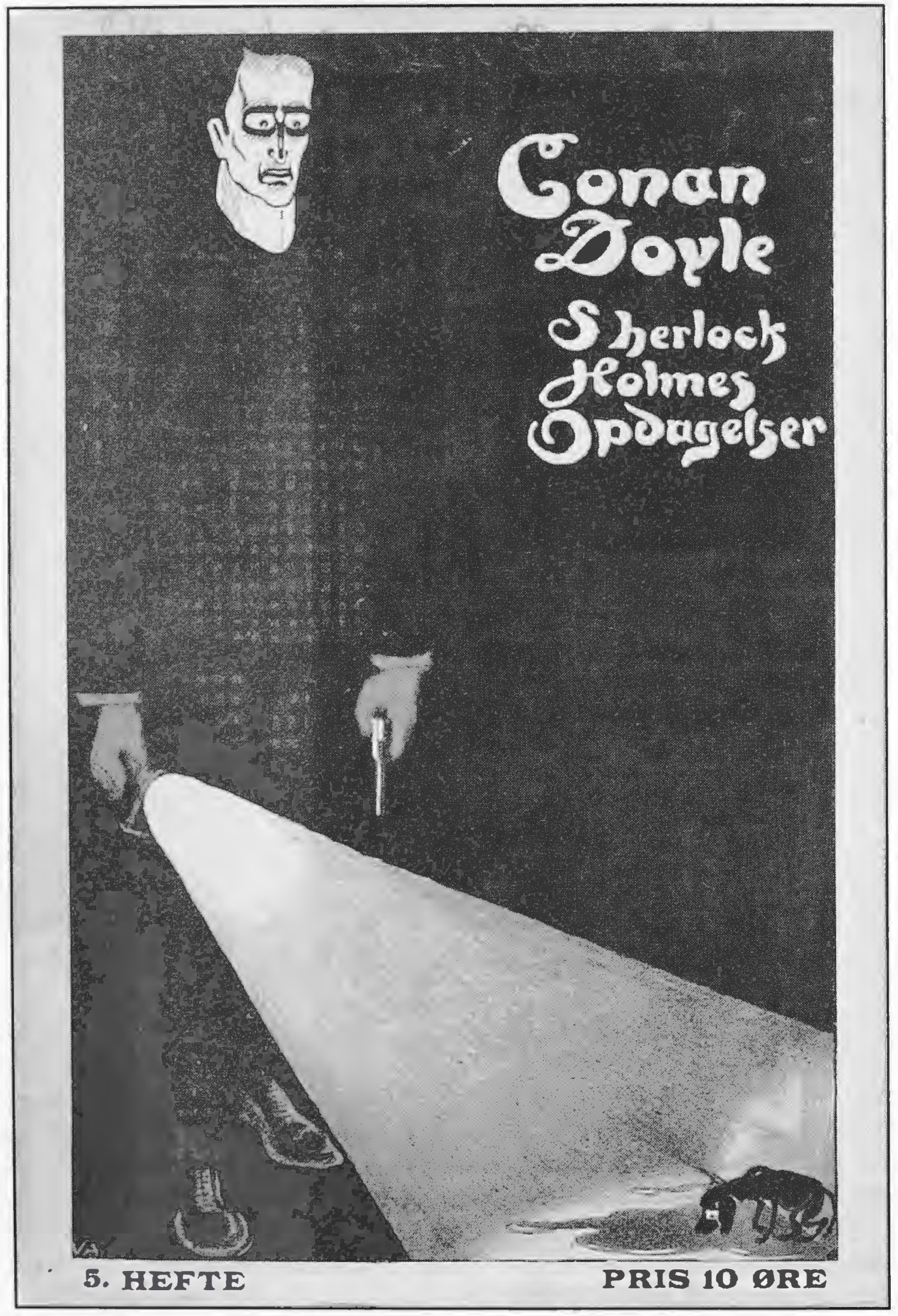




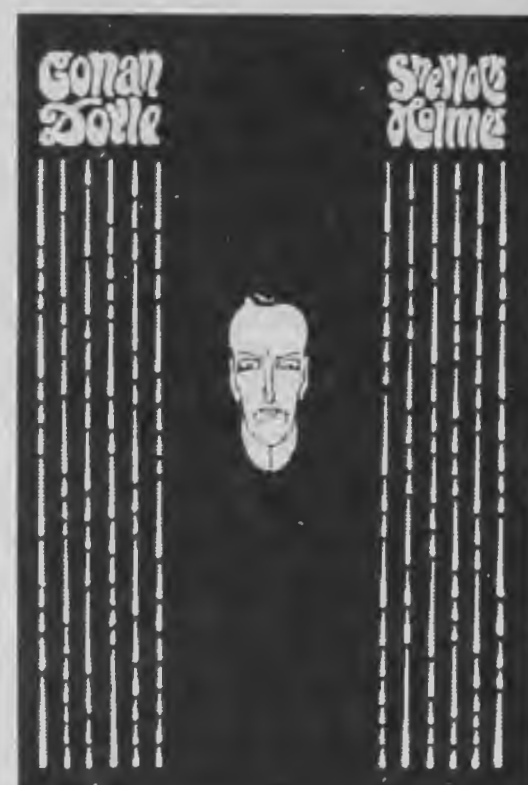

ILLUSTRATION AF.. BINDET TIL SHERLOCK ......... HOLMES
BIND TIL SHERLOCK HOLMES

Da Forlaget mener, al det $\int^{2}$ vil vare af Belydning for de fleste af Subskribenterne paa

SHERLOCK HOLMES OPDAGELSER at holde dette Vark som et simlet Hele, kommer vi mange Xnsker i Morle ved nu al fremstille th billigt og starkt lBind, som om kort 'Tid foreligger til 1ste 13ind. lïnsineren Vatdenan ANDERsen har til dette leveret en udmaxk at 'Tegning, som trykkes $\mathrm{i}$ hvid og rest Farve paa sort Shirting. Prisen er s() $)$.

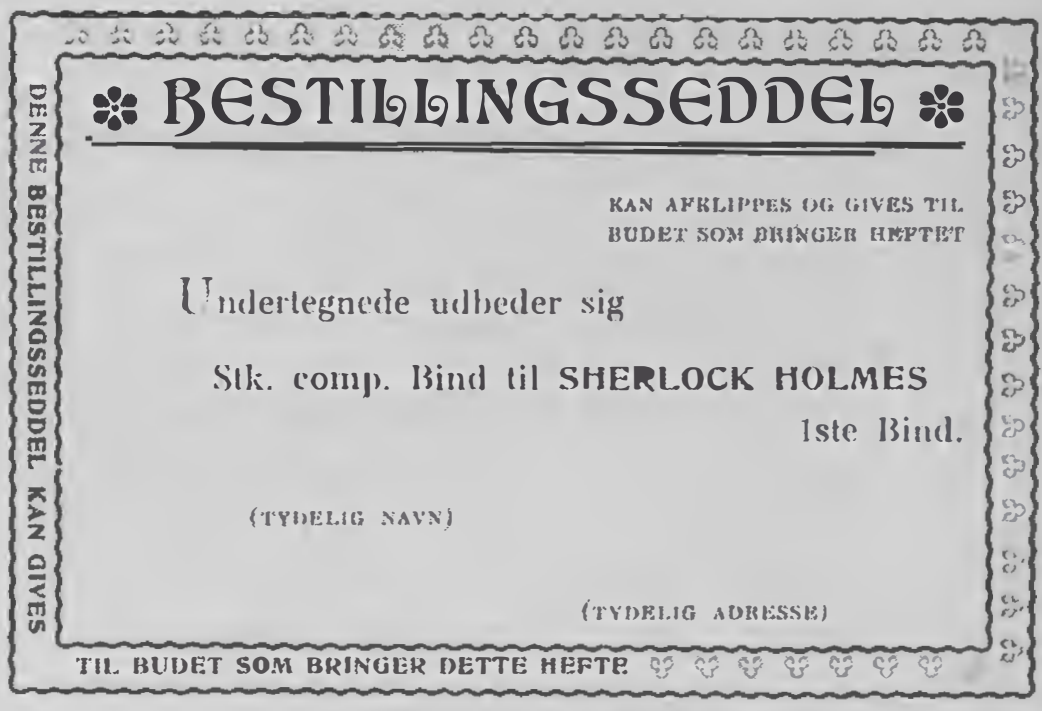

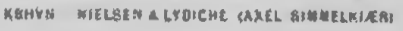

På foregående side ses VAs omslagstegning til subskriptionshefterne $i$ sort/hvidt (Gyldendal 1905). - På denne side oplyses subskribenterne om det planlagte forlagsbind $i$ en annonce, hvori bindet er afbildet. Den endelige grundfarve blev dog purpurgrå (Gyldendal 1905). 


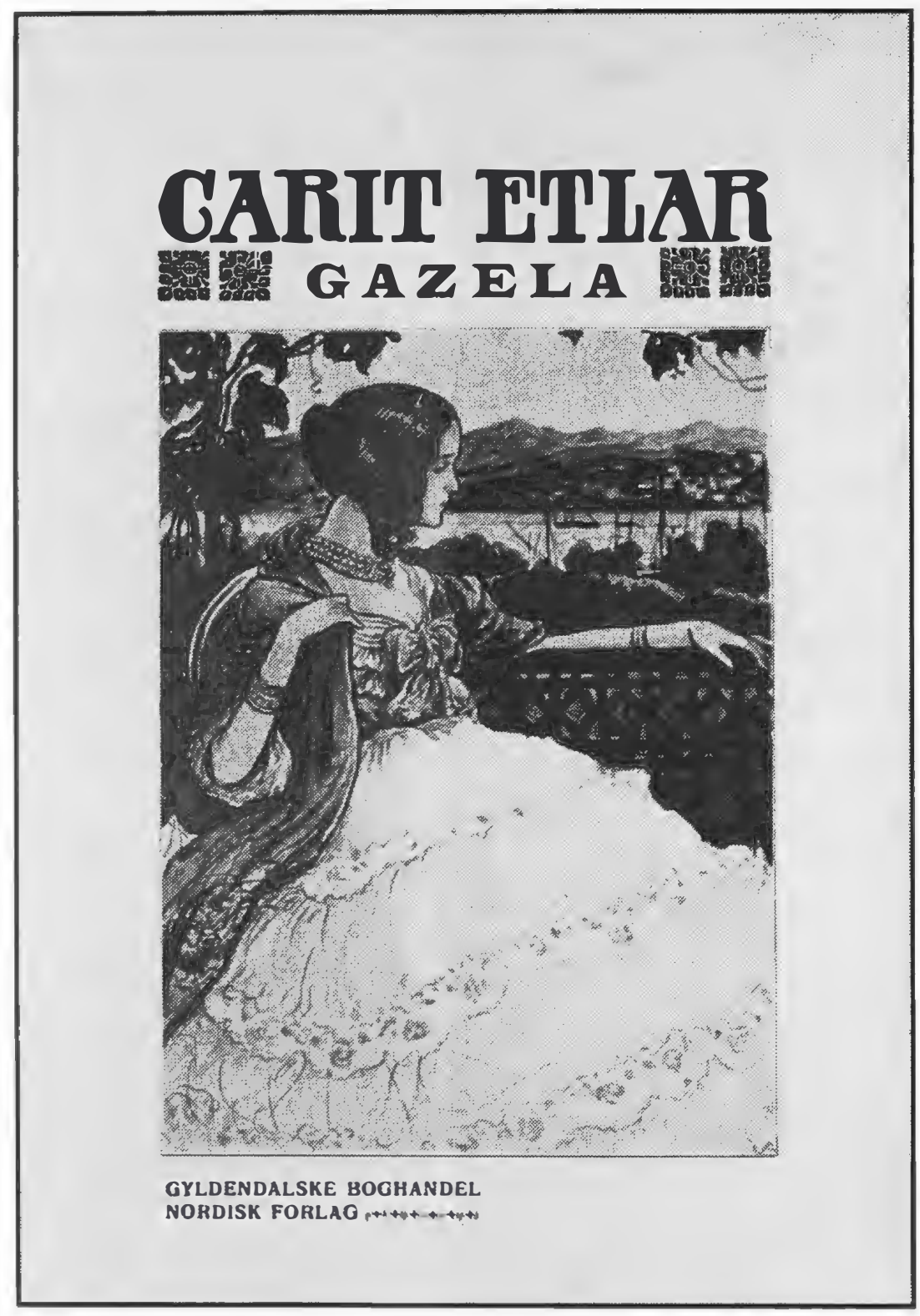

Omslag af VA til subskriptionshefte i sort/hvidt (Gyldendal 1905).

stillet et billigt og stærkt bind til en pris af 50 øre, samt at 'Kunstneren Valdemar Andersen har til dette leveret en udmærket Tegning, som trykkes i hvid og rød Farve paa sort Shirting'. Ophavet til det usignerede bind er således med sikkerhed VA, men meddelelsen afslører også, at hạn oprindelig havde tænkt sig dekorationen udført på sort bund.
Bindfarven blev faktisk purpurgrå. Forfatter og titel står i rødt over en stregdekoration fordelt på forpermens langsider, og midt på bindet lyser et smalt intellektuelt, lidt spøgelsesagtigt ansigt i sort/hvidt, naturligvis selveste Sherlock Holmes.

Enkelt, men ikke uden effekt, man fristes til at sige 'elementary ...'. 


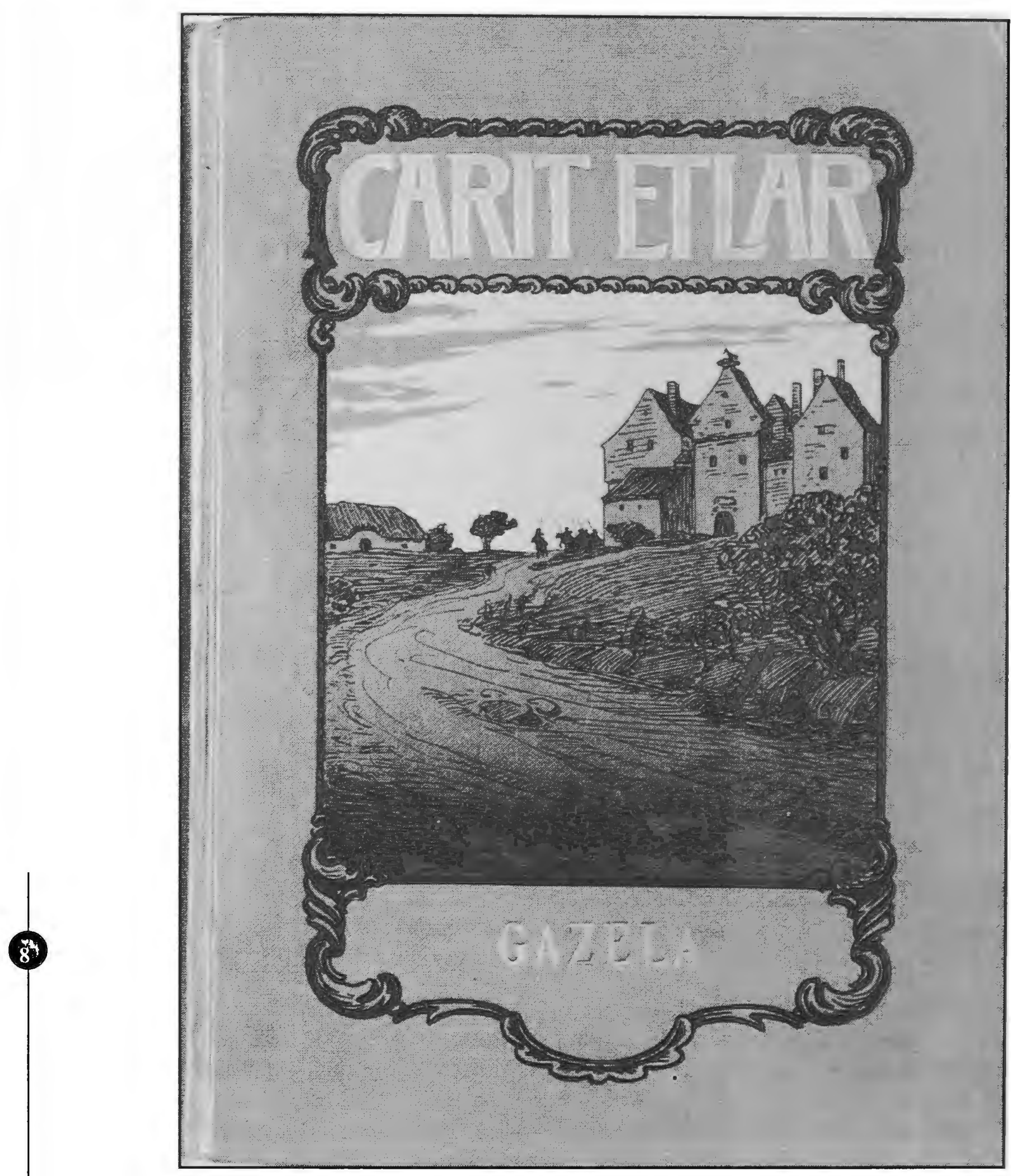

Standardbind i rodt og guld med farvelagt tegning af $F$ (rants) H(enningsen) (Gyldendal 1906). 


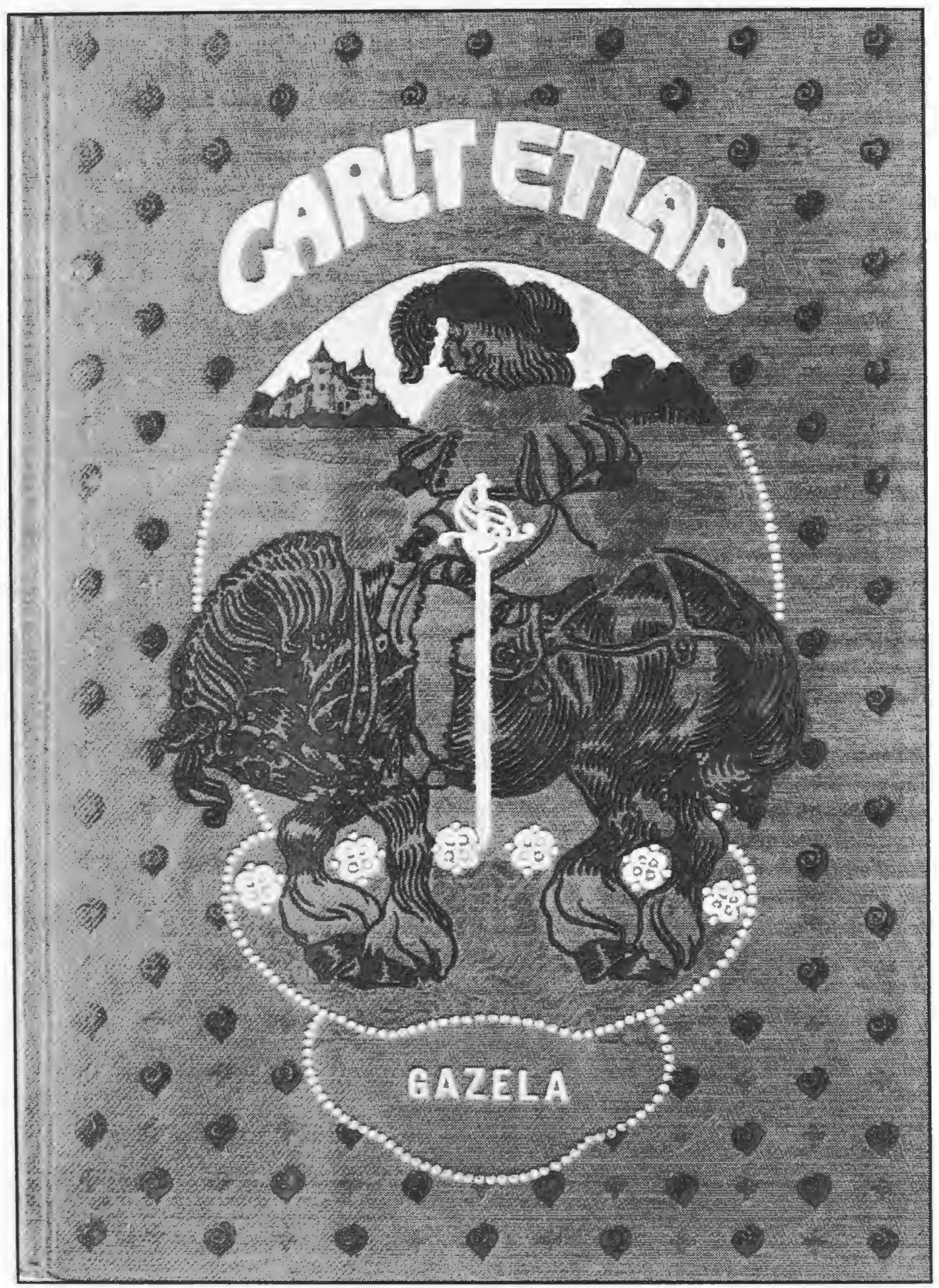

Standardbind i rodt med dekoration i guld, sort og gräblait, sandsynligvis tegnet af VA (Gyldendal 1906). 


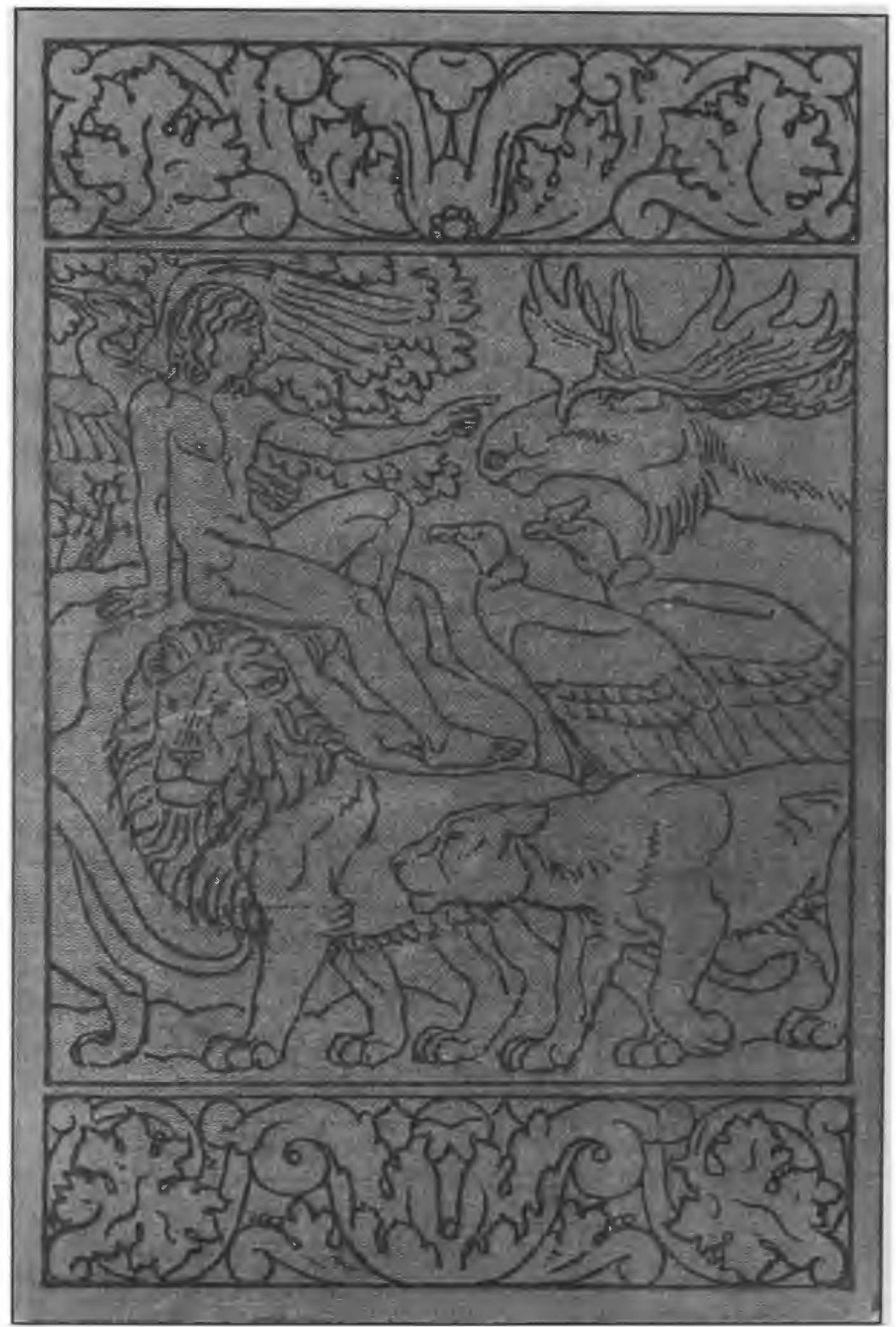

Bind udfort for bogbinderfirmaet Petersen og Petersen i gront og sort af Joakim Skovgaard og Th. Bindesboll (1907). 


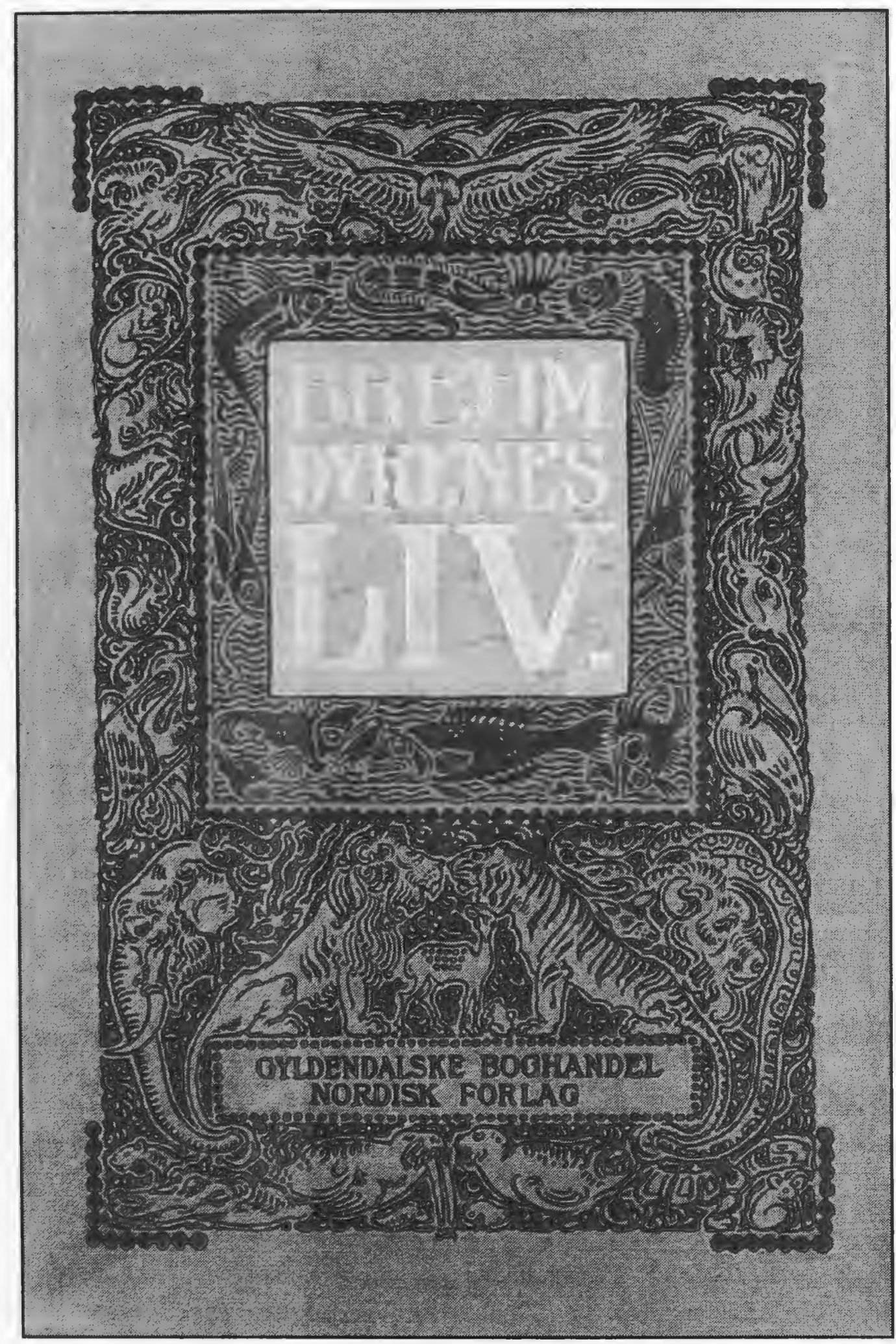

Forlagsbindet udfort af VA i sort, gråt og guld på lysebrun bund (Gyldendal 1907). 
I de samme år, 1905-06, benyttede Gyldendal Andersen som illustrator til en udgave i ti bind af Carit Etlars fortællinger, der skulle konkurrere med Pios store udgave af hans skrifter illustreret af Poul Steffensen. Hertil leverede han både tegninger i sort/hvidt og farver, udførte de farvetrykte omslag og komponerede efter alt at dømme det festlige røde standardbind. Midt på forsiden er placeret en figur fra en af Etlars historiske fortællinger, en udstafferet kavaller på en fyrig ganger $i$ en brudt ramme af forgyldte prikker. Kavalleren rækker tunge mod en borg i baggrunden, og som på Danmarks Vovehals er hans profil udført i relief på forgyldt baggrund. Uden om figuren er anbragt rækker af dekorative elementer i sort og blàt. Kompositionen er uden signatur, men kan næppe skyldes nogen anden end VA, selv om bindet står i kontrast til de fleste af omslagene. F.eks. har han valgt at tegne omslaget til Gazela i en stil, som af mangel på bedre betegnelse kan kaldes mondæn. Han bevægede sig ubesværet fra den ene stilart til den anden, og bindtegningen turde ikke være mindre karakteristisk for hans kunst end omslaget. Mærkeligt nok lod forlaget (før eller senere?) fremstille endnu et standardbind, også dette rødt, der domineres af en farvelagt tegning af en landevej, som fører op til en middelalderborg. Jævnt kedeligt som det er understreger det kvaliteten af Andersens arbejde. Tegningen er signeret $\mathrm{FH}$ og vel altså udført af Frants Henningsen.

I 1907 tegnede VA illustrationer og bind til Gyldendals udgave af Stor-Kobenhavn ved Gnudtzmann og
Lind (bindet ikke set) og samme år tre bind af Brehms Dyrenes Liv, der udkom som det sidste værk i serien af 'Frem's populærvidenskabelige bøger. Som på seriens øvrige bind skulle binddekorationen signalere indholdet, og dette skete med en tæt komposition af dyreskikkelser tegnet omkring titel og forlagsangivelse. Bindfarven er i en lys brunlig tone, titel i guld og forlagsangivelse i sort, dyredekorationen holdt i grå-sorte streger. Stilen minder om nogle af de senere omslag til Kiplings bøger.

Det er nok mest en smagssag, om man vil foretrække dette (af VA signerede) bind eller det tilsvarende, som bogbinderfirmaet Petersen og Petersen lod tegne af Joakim Skovgaard og Th. Bindesbøll. Skovgaard og Bindesbøll har under alle omstændigheder det fortrin, at de bygger på en rammende ide: Med sort på grøn bund er på forsiden tegnet en paradisisk idyl med en siddende Adam, der giver dyrene navne. Brede grenborter foroven og forneden, som ikke har levnet plads til tekster på bindsiden, gentages bag på bindet, hvor der midtpå er tegnet et dyrekranium.

1908 kom turen til atter en skønlitterær bog, Holger Drachmanns Forskrevet, i hvad Gyldendal benævnte 'anden særskilte Folkeudgave'. Det blånistrede shirtingsbind er som det forrige signeret VA og morsomt dekoreret med forfatterens letgenkendelige fysiognomi i guld omgivet af bølgende streger og prydelementer i guld og rødbrun farve. Det er det eneste af de her omtalte bind, hvor VA åbenbart ikke har været bundet til at lade forfatternavn og titel indgå $\mathrm{i}$ forsidedekorationen. 


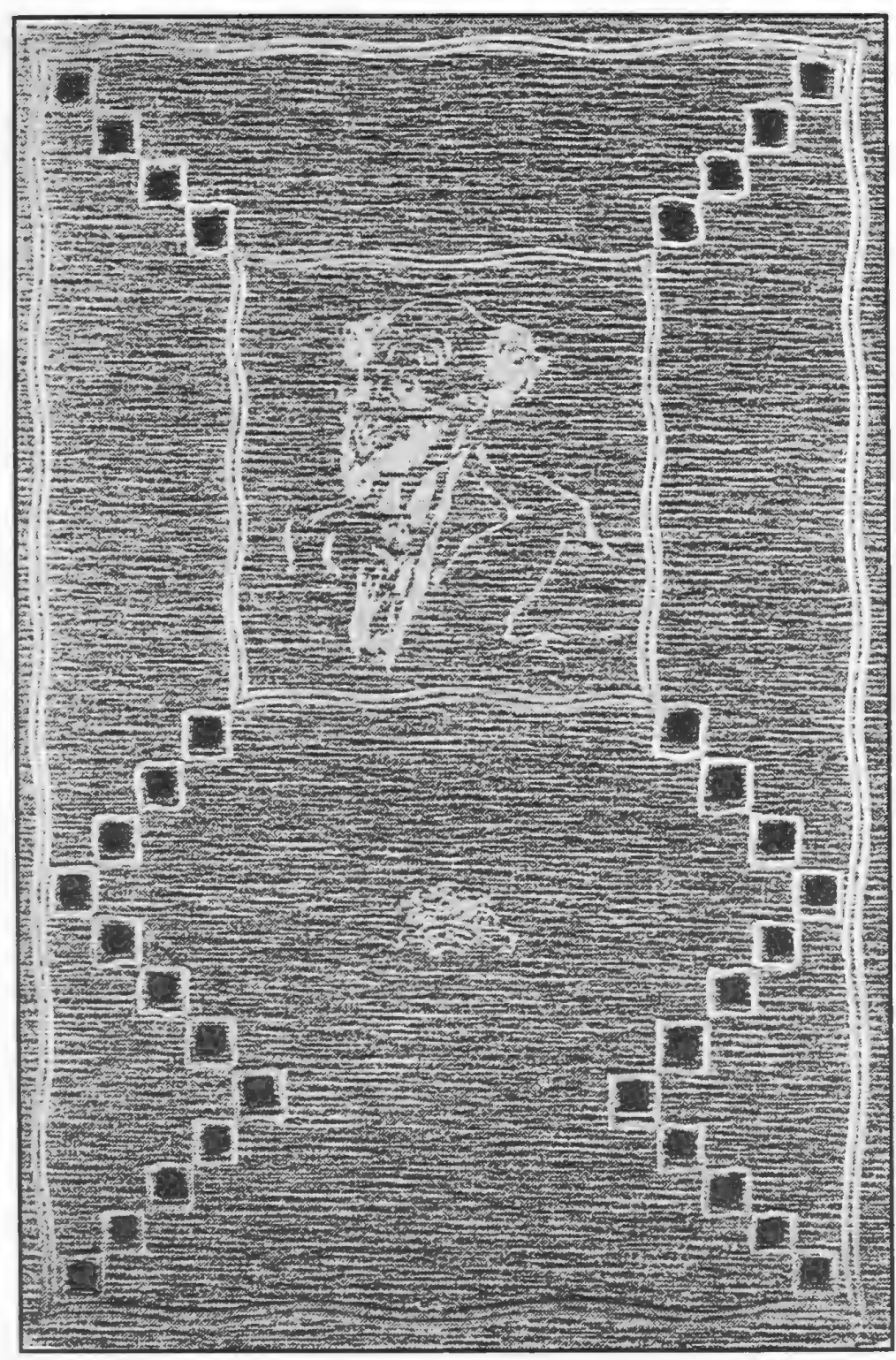

Holger Drachmann: 'Forskrevet' i blanistret bind med dekoration $i$ guld og rodbrunt (Gyldendal 1908).

Det følgende år udsendte Andr. Høsts forlag den historiske roman Niels Juel af P.P. (Th. Rumohr), hvori der nedsænket i det kraftige bind, lige-ledes af blånistret shirting, er påmonteret en koloreret tegning med et orlogsskib. Tegningen er signeret VA, men om han haft ansvar for bindet som helhed er uvist.
Efter 1912, da VA udførte det sidste bind i Gyldendals serie, synes han kun sporadisk at have arbejdet med bogbind. Han havde ansvaret for bogudstyret af Johs. V. Jensens Skrifter, der kom i otte bind hos Gyldendal 1916, og samme år lod V. Pios Boghandel ham tegne rygdekorationen til et skindbind om 50 nummererede eksemplarer af nogle Kip- 
lingbøger trykt på svært papir (Meddelelse fra forlaget nr. 76 (1916) og nr. 103 (1917). Et af hans formentlig sidste bind er omtalt i kunsttidsskriftet Samleren, hvor det i december-nummeret for 1924 blev kundgjort for abonnenterne, at bogbinder Anker Kyster havde ladet VA komponere et bind til den nys afsluttede årgang. Bindet er ikke set in natura, men af et foto gengivet sammesteds fremgår, at det var et halvbind med dekoreret ryg og mønstret overtrækspapir. VA har i en fødselsdagshilsen til Kyster givet udtryk for, at han satte pris på samarbejdet med den dygtige og kræsne bogbindermester (H.P. Rohde: Anker Kyster, 1982, s.

157f). Men blev samarbejdet mon som han håbede forsat? Det giver Rohdes bog ikke svar på, og det skal på ingen måde hævdes, at der med disse strejftog er sagt det sidste ord om Valdemar Andersens virksomhed som bindtegner.

Tillag: Forlagsbind tegnet af Valdemar Andersen i 'Gyldendals Bibliothek'

\section{Dokumenterede.}

Holger Drachmann: Fortellinger. 1908 (nr. 16).

Vilhelm Østergaard: Tyge Brahe. 1907 (nr. 80).

Clara Tschudi: Eugénie. 1910 (nr. 99). Einar Christiansen: Joppe. 1911 (nr. 123).
Knut Hamsun: Victoria. 1911 (nr. 124). Kristofer Janson: Hjordis. 1911 (nr. 125).

Harald Molander: En Lykkeridder. 1911 (nr. 126).

Carsten Hauch: Vilhelm Zabern. 1911

(nr. 127).

Laurids Bruun: Kronen. 1911 (nr. 128).

Vilhelm Østergaard: Danmarks Vovehals.

1912 (nr. 129).

Johannes Jørgensen: Den yderste Dag.

1912 (nr. 130).

Johan Bojer: Troens Magt. 1912 (nr.

131).

Bernt Lie: I Eventyrland. 1912 (nr. 132).

L. Mylius-Erichsen: Fra Klit og Hav.

1912 (nr. 133).

Daniel Fallström: Sorte og rode Hjorter.

1912 (nr. 134).

\section{Tilskrevne.}

Zacharias Topelius: Gustav Adolf og Trediveaarskrigen. 1910 (nr. 111).

P.Fr. Rist: Lasse Månsson fra Skaane. 1912 (nr. 137).

\section{Iovrigt:}

Foruden VA-omslag omtalt i Poul Carit Andersens ovenfor citerede bog og Weilbach tegnede han 1916 for Aschehougs forlag omslaget til Patrick MacGill: Den rode Horizont. Desuden kan der henvises til Magasin 2. årg. nr. 4 1987, hvor der s. 8, 11 og 17 vises nogle omslag til bøger af Kipling. 